\title{
CONTROLLING OF CREDIT DEBTS IN THE SYSTEM OF ANTI-CRISIS FINANCIAL MANAGEMENT
}

\author{
Kushchik A. P. \\ Zaporizhzhya National University \\ Ukraine, 69600, Zaporizhzhia, Zhukovsky str., 66 \\ 20favorit10@i.ua \\ ORCID 0000-0003-0627-2296
}

Key words:

controlling, credit debts, capital turnover, financial cycle, financial resources, cash flows.
The article deals with topical issues of introduction of controlling of credit debts in the system of anti-crisis financial management of the enterprise. It is noted that effective management of credit debts of industrial enterprises in the conditions of working capital deficit taking into account aspects of its strategic development and specific tactical goals is an integrity process in general involving modification and application of alternative concepts of capital management of the enterprise which is adequate to market transformational market economy of Ukraine. It is established that the mechanism of credit debts management is a part of the overall financial strategy, which is providing the most effective forms and conditions for raising borrowed capital from various sources in accordance with the needs of enterprise development. A method of liability analysis is proposed, the main task of which is to identify signs of insolvency of the enterprise and preventing its bankruptcy. The essence of the proposed method is to study the structure of liabilities, their turnover, to determine the degree of solvency and liquidity of the enterprise, as well as to calculate the maximum amount of liabilities under the influence of such factors as profit, of enterprise and circulating expenses assets. It is noted that the optimization of credit debts is an important aspect of the enterprise, as it is an integral part of modern business. Effective management and optimization of credit debts can be a relatively inexpensive and additional source of financial resources, and, consequently, an important element of the system of anticrisis financial management of the enterprise.

\section{КОНТРОЛІНГ КРЕДИТОРСЬКОЇ ЗАБОРГОВАНОСТІ В СИСТЕМІ АНТИКРИЗОВОГО ФІНАНСОВОГО УПРАВЛІННЯ}

\author{
Кущик А.П. \\ Запорізький національний університет \\ Україна, 69600, м. Запоріжжя, вул. Жуковського, 66
}

\begin{abstract}
Ключові слова:
контролінг, кредиторська заборгованість, оборотність капіталу, фінансовий цикл, фінансові ресурси, грошові потоки.
\end{abstract}

У статті розглянуто актуальні питання впровадження контролінгу кредиторської заборгованості в системі антикризового фінансового управління підприємством. Зазначено, що ефективне управління кредиторською заборгованістю промислових підприємств в умовах дефіциту оборотних коштів з урахуванням аспектів його стратегічного розвитку та конкретних тактичних цілей $є$ цілісним процесом, що передбачає модифікацію та застосування альтернативних концепцій управління капіталом підприємства загалом, а також методів оцінки ефективності його функціонування, адекватних умовам трансформаційної ринкової економіки України. Встановлено, що механізм управління кредиторською заборгованістю являє собою частину загальної фінансової стратегії, яка полягає в забезпеченні найбільш ефективних форм і умов залучення позикового капіталу з різних джерел відповідно до потреб розвитку підприємства. Запропоновано методику аналізу зобов'язань, основним завданням якої є виявлення ознак неплатоспроможності підприємства та запобігання його банкрутству. Сутність запропонованої методики полягає у вивченні структури зобов'язань, їх оборотності, визначенні ступеня платоспроможності та ліквідності підприємства, а також у здійсненні розрахунку граничної суми зобов'язань під впливом таких чинників як доходи, витрати діяльності, оборотні активи підприємства. Зазначено, що оптимізація кредиторської заборгованістю є важливим аспектом в діяльності підприємства, оскільки є невід’ємною складовою в функціонуванні сучасного бізнесу. Ефективне управління та оптимізація кредиторської заборгованості може стати порівняно недорогим та додатковим джерелом залучення фінансових ресурсів, а, від так, важливим елементом системи антикризового фінансового управління підприємством. 


\section{Statement of problem}

Credit debts management promotes the circulation of funds in the production process and is a public recognition that the company has fulfilled its production obligations and goals. Optimization of the amount of credit debts involves the formation of such a size that can attract the necessary short-term funds, as well on a free basis; also can ensure the receipt of the necessary profit from the sale and maintain an acceptable level of financial risk, and provide a sufficiently high rate of turnover in the calculations, too.

Timely paying off credit debts, the optimal amount of credit debts in relation to debitorliabilities others and largely determine the financial stability of the enterprise. Significant and uncontrolled growth of credit debts leads to loss of control over the amount of long-term and current liabilities, and in some cases - to the bankruptcy of the enterprise. This involves the development and implementation of strategies that ensure the achievement of the planned level of market positioning through their constant adaptation to changes in the competitive environment. In the context of the crisis of accounts, it is important to study methodological approaches to the optimization of credit debts as an integral element of anticrisis management.

\section{Analysis of recent studies and publications}

The research of credit debts management is devoted to the works of such foreign scholars, as: L. A. Bernstein, M. F. Van Bred, E. S. Hendrixen and others. Among domestic scientists, problematic aspects of credit debts management were studied by such specialists as: L. M. Bratchuk, F. F. Butynets, Yu. A. Veriga, G. V. Vlasyuk, S. F. Golov, O. E. Gudz, V. M. Dobrovsky, E. I. Maslennikov, M. F. Ogiychuk, O. M. Petruk, O. V. Poberezhets, L. K. Suk, P. Ya. Khomin, S. V. Filippova, E. F. Yugas and others.

Despite the long history of the study of credit debts, in the modern scientific literature there is no consensus on the interpretation of this concept.

Thus, A. B. Borisov defines credit debts as financial resources that are temporarily subordinated to the enterprise and firm which subject to return to a legal or physical personality, in whose they are borrowed and to whom they are not paid [1].

Butynets F. F, Goretska L. L. consider credit debts as a form of payment for goods and services purchased during the company's operations, which are periodically repeated and used in production (in the capacity of raw materials) or for resale (otherwise it is called accounts payable or trade accounts payable) [2].

Credit debts, according to I. A. Blank is the current liabilities of the enterprise, reflecting its debts before business partners from commercial transactions, accounts payable, etc. [3].

Despite significant scientific developments, it should be noted that a number of problems in the study of this topic remain unresolved, so, in particular, it is advisable to develop a methodology for optimizing the amount of accounts payable in anticrisis management.

\section{Objectives of the article}

The purpose of the article is to improve the organizational and methodological aspects of managing credit debts of an industrial enterprise in the system of anticrisis financial management. In accordance with the target direction, the following tasks are set that is: to consider the theoretical and methodological foundations of managing credit debts of the enterprise; to study the management mechanism and methods of optimization of credit debts and to identify areas for improving the management of credit debts.

\section{The main material of the research}

Optimization of sources of financial resources is one of the main tasks of anticrisis management of the enterprise, because the excess of funds reduces the efficiency of using, and in case of shortage there are financial difficulties that can lead to serious negative consequences. In addition, the optimal distribution of the formation of sources of financial resources is one of the ways to obtain the highest financial result [4].

Debt greatly affects the financial and property condition of the enterprise, especially the formation and use of its financial resources, monetary flows, as it is a prerequisite or consequence of the calculated relationships of the enterprise with its counterparties.

Depending on the procedure for determining the amount of accounts payable can be classified as follows (fig. 1):

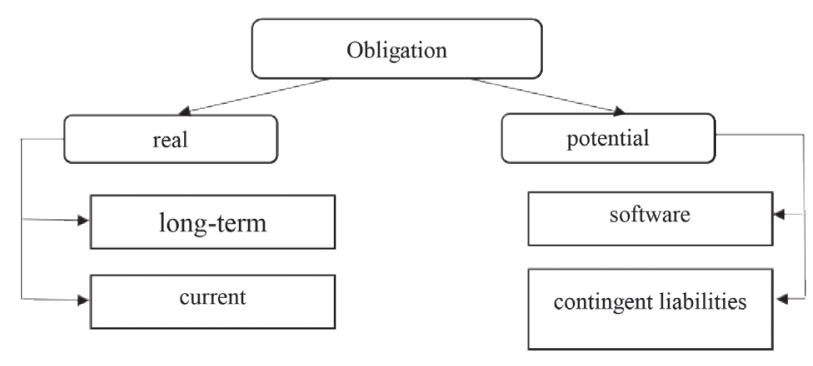

Fig. 1. Scheme of classification of credit debts

Also, based on practical necessity, for the needs of management (shareholders, management) it would be appropriate to allocate from the general classification of the amount of overdue credit debts, which is formed as a result of violation by buyers the procedure and terms of payment of calculating documents.

Separation of this type of liability is necessary to control the amount of overdue credit debts, establish the reality of its repayment, calculate partial indicators of financial stability and solvency of the enterprise, and for debts whose statute of expenses limitations has expired is timely reflection of profits and expenses of the enterprise [5].

As a form of borrowed capital used by the enterprise in the process of its economic activity, credit debts are characterized by the following main features:

- credit debts for the company is, to a large extent, a free source of borrowed funds. The higher the share of credit debts in the total amount of capital used by the enterprise, the correspondingly lower (by other equal conditions) will be the weighted average cost of its capital.

- the amount of credit debts, expressed in days of its turnover, affects the duration of the financial cycle of the enterprise. 
The higher the relative amount of credit debts, the smaller the amount of funds (by other equal conditions) the company needs to raise to finance its current business activities.

- the amount of credit debts formed by the enterprise is directly dependent on the volume of economic activity of the enterprise, in the first place from the volume of production and sales. With the growth of production and sales increases the costs of the enterprise, which are included in its credit debts, and, accordingly, increases its total amount, and vice versa. Therefore, with a constant ratio of financial leverage, the development of operating activities of the enterprise does not increase its relative need for credit.

- the projected amount of credit debts for most types is only approximate. This is due to the fact that the size of many accruals that are part of credit debts, are not subject to accurate quantitative calculation due to the uncertainty of many parameters of future economic activity of the enterprise.

- the amount of credit debts for its individual types and for the enterprise as a whole depends on the frequency of payments (repayment of liabilities). The periodicity of these payments is regulated by state regulations, the terms of contracts with business partners and only a small part of them by internal regulations of the enterprise. This high degree of dependence of the periodicity of payments (and, accordingly, the amount of accruals) on individual accounts, which is part of credit debts, on external factors determines the low level of regulation of this source of borrowed funds in the financial management process [6].

These features of credit debts must be taken into account in the process of crisis management at the enterprise.

After assessing credit debts in the context of the financial stability of the entity, it is necessary to determine the reasons for its occurrence and the optimal mechanism for its management.
The credit debts management model includes the following components:

- substantiation of expediency of receiving a determent of payment of suppliers' bills, as well as the optimal term of such determent;

- static and dynamic analysis of the formation and repayment of credit debts of the entity and its impact on the amount of its financial flows;

- prevention of the formation of overdue credit debts and ensuring, if necessary, the prolongation of credit debts.

A prerequisite for achieving controllability of the process of calculations with suppliers and contractors is the automation of their accounting, which helps to increase its analytics and efficiency through improved information exchange and increase the reliability of information [7].

Thus, as a result of research of measures for increasing the efficiency of management of credit debts, the mechanism of effective management is offered (fig. 2).

Taking into account this goal, the management of credit debts of the enterprise is based on the following main stages:

1. Analysis of credit debts of the enterprise in the previous period and identification of the potential for the formation of borrowed funds of the enterprise from this source. Initially, the dynamics of the total amount of credit debts of the enterprise in the previous period is being investigated and also the change in its share in the total amount of borrowed capital. Then the turnover of credit debts of the enterprise is considered, its role in formation of its financial cycle is revealed. The next step of the analysis is to study the composition of credit debts by its individual types; identification of the dynamics of the share of its individual species in the total amount of credit debts; checking the timeliness of accrual and payment of funds on individual accounts. Upon completion of the analysis, the dependence of changes in certain types of credit debts on changes in sales is studied and the coefficient of its elasticity is calculated.

2. Determining the composition of credit debts of the enterprise in the future. In the process of this stage, a list of specific types of credit debts of the enterprise is established, taking into account new types of business transactions (ex personal insurance of personnel), new activities, new internal structures of the enterprise, new types of mandatory payments and others.

3. Establishment of periodicity of payments on separate types of credit debts. At this stage, for each type of credit debts, the average accrual period is set from the moment of accrual to the implementation of their payments. For this purpose, specific terms of payment of certain taxes, fees and deductions to the budget and extra-budgetary funds, the frequency of payment of insurance premiums in accordance with insurance contracts, terms of payment of wages in accordance with the collective agreement, etc. are considered.

Fig. 2. The mechanism of the system of effective management of credit debts 
4. Forecasting the average amount of accrued payments for certain types of credit debts. Such forecasting is carried out by two main methods: a) the method of direct calculation. This method is used in cases where certain types of credit debts are known in advance the amount of payments. b) statistical method based on coefficients of elasticity. This method is used in cases where the amount of payments for a particular type of credit debts is not clearly defined in advance.

5. Forecasting the average amount and amount of growth of credit debts for the enterprise as a whole. It is determined by summing its projected average size for individual types of this debt.

6. Assessment of the effect of growth of credit debts of the enterprise in the future. This effect means to reduce the company's need to obtain credit and the costs associated with its maintenance.

7. Ensuring control over the timely accrual and payment of funds in terms of certain types of credit debts. The payment of these funds is included in the developed payment calendar and is controlled in the process of monitoring the current financial activities of the enterprise [8]. Credit debts management based on its analysis will help the company to optimize the amount of credit debts, ie to form such a size that:

- will attract the necessary short-term borrowed funds on a free basis to finance certain elements of current assets (including debitor's debts);

- will promote the growth of financial results of the enterprise;

- provide the necessary profit from the sale;

- ensure the preservation of acceptable level of risk of non-payment of payments by the company for its obligations;

- will provide a sufficiently high rate of turnover in calculations.

\section{Conclusions}

On the one hand, using by a business credit money expands its financial capabilities in operative maneuvering the sources covering its needs, but at the same time creates the risk of losing financial stability due to the forced return of them in significant amounts in future.

Ensuring effective management of credit debts of the enterprise will allow to eliminate the negative consequences of its existence. Optimization of credit debts is an important aspect of the enterprise, as it is an integral part of modern business. Effective credit debts management can be a relatively inexpensive and be an additional source of financial resources.

The main rules that should guide the company in the process of effective crisis management of its credit debts are as follows:

- substantiation of credit debts, analysis of orders and execution of calculations.

- determining the policy under which the loan will be provided and the terms of collection for different groups of debtors and creditors.

- analysis and ranking of debtors and creditors depending on the size of purchases, the proposed terms of payment and the history of credit relationships, the definition of unfavorable types of goods as for encashment.

- control of mutual calculations with debtors and creditors on deferred or overdue debts, determining the causes of violations of contractual discipline and the real value of existing creditor and debitor debts of the enterprise.

- timely identification of means to accelerate the turnover of current assets and reduce the amount of bad debts.

- providing conditions of sale that will guarantee the receipt of cash funds, as well as the implementation of prognosis of receipls based on the terms of encashment.

\section{References}

1. Borysov A. B. (2010). Bolshoy entsyklopedicheskiy slovar. [Large encyclopedic dictionary]. Moscow: Knizhniy myr. [in Russia].

2. Blanc I. A. (2011). Upravlynnya finansovimy resursamy. [Financial resources management]. Kiyv: Omega-L. [in Ukrainian].

3. Butinets F. F. (20013). Economichniy analys: navchalniy posybnic. [Economic analysis: a textbook]. Zhytomyr: Ruta. [in Ukrainian].

4. Zaglada R. N. (2009). Kontroling yak Sistema effektivnogo upravlinnya pidpriemstvom. [Controlling as a system of effective enterprise management]. Economica - Economy, 4, 12-15 [in Ukrainian].

5. Gnatenko E. P. (2015). Analis spivvidnpshennya debitprskoy ta kreditorskoy zaborgovanosti pidpriemstva. [Analysis of the ratio of receivables and payables of the enterprise]. Naukoviy visnik MNU imeny V. O. Suhomlinskogo. Economichny nauki - Scientific Bulletin of MNU named after VO Sukhomlinsky. Economic sciences, 1(4), 38-42 [in Ukrainian].

6. Dombrovska N.R. (2015). Debitorska ta kreditorska zaborgovanosti: problem kvalifykastii. [Accounts receivable and payable: classification problems]. Inovastiyna economika - Innovative economy, 1(50), 182-87 [in Ukrainian].

7. Kolesnichenko V. E. (2016). Analis upravlinnya kreditorskoyu zaborgovanistyu. [Accounts payable management analysis]. Efectivna economika - Efficient economy, 3, 23-28 [in Ukrainian].

8. Novistka N. V. (2016). Teoretichny aspekti ponyat "debitorska zaborgovanist" I "kreditorska zaborgovanist" [Theoretical aspects of the concepts of "receivables" and "accounts payable"]. Aktualny problem economyki Current economic problems, 2, 286-290 [in Ukrainian]. 